\title{
Crystallinity-Controlled Synthesis of Zirconium Oxide Thin Films on Nitrogen-Doped Carbon Nanotubes by Atomic Layer Deposition
}

\author{
Jian Liu, ${ }^{\dagger}$ Xiangbo Meng, ${ }^{\ddagger}$ Mohammad Norouzi Banis, ${ }^{\dagger}$ Mei Cai, ${ }^{\S}$ Ruying Li, ${ }^{\dagger}$ and Xueliang Sun ${ }^{*}, \dagger$ \\ ${ }^{\dagger}$ Department of Mechanical and Materials Engineering, University of Western Ontario, London, Ontario, Canada N6A 5B9 \\ ${ }^{\ddagger}$ Chemistry Department, Brookhaven National Laboratory, Upton, New York 11973, United States \\ ${ }^{\S}$ General Motors R\&D Center, Warren, Michigan 48090-9055, United States
}

Supporting Information

ABSTRACT: Zirconium oxide $\left(\mathrm{ZrO}_{2}\right)$ thin film was deposited on nitrogen-doped carbon nanotubes (NCNTs) by atomic layer deposition (ALD) using tetrakis(dimethylamido)zirconium(IV) and water as precursors. The observation using scanning electron microscope and transmission electron microscope (TEM) revealed that the tubular films of 100 -cycle $\mathrm{ZrO}_{2}$ were very uniform and conformal on NCNTs. Further characterization using X-ray diffraction, Raman spectroscopy, selected area electron diffraction, and high-resolution TEM disclosed that the crystallinity of the deposited $\mathrm{ZrO}_{2}$ films was controllable with deposition temperatures in the range of $100-250{ }^{\circ} \mathrm{C}$. In contrast to the pure amorphous $\mathrm{ZrO}_{2}$ film deposited at $100{ }^{\circ} \mathrm{C}$, tetragonal crystalline $\mathrm{ZrO}_{2}$ film was prepared at 250 ${ }^{\circ} \mathrm{C}$, while a mixture of the former two phases was found between 150 and $200{ }^{\circ} \mathrm{C}$. In

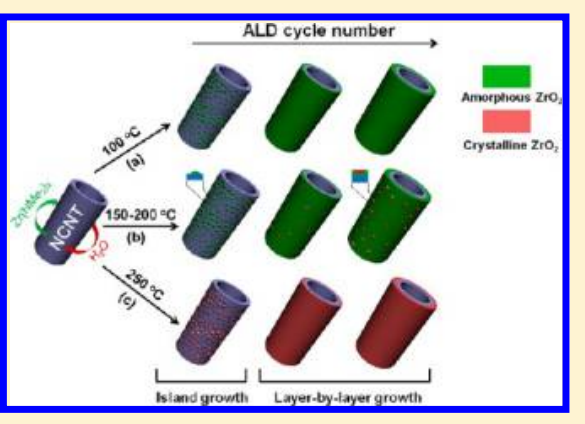
all cases, the growth of $\mathrm{ZrO}_{2}$ tubular films on NCNTs showed a transformation from an island-growth mode to a layer-by-layer growth mode with increasing ALD cycles. The $\mathrm{ZrO}_{2}-\mathrm{NCNT}$ nanocomposites with controllable crystallinity will have great potential for various applications in fuel cells, batteries, electronics devices, and chemical sensors.

\section{INTRODUCTION}

Since the work by Iijima in $1991,{ }^{1}$ carbon nanotubes (CNTs) have been drawing much attention from various areas because of their unique properties. ${ }^{2,3} \mathrm{Up}$ to now, CNTs have been involved in a wide range of potential applications, such as reinforced materials, nanoelectronic devices, field emission display sources, and energy storage and conversion devices. ${ }^{4,5}$ Recently, great interest has been raised to make onedimensional nanocomposites by using CNTs as supports for the deposition of various materials. ${ }^{6-9}$ In particular, CNTs have been considered as the most promising templates for fabricating metal oxide-CNT nanocomposites, which possess exceptional chemical, mechanical, and physical properties. ${ }^{10-15}$ These advanced nanocomposites are likely to become key components in the next generation of magnetic, optical, and electronic devices.

Zirconium oxide $\left(\mathrm{ZrO}_{2}\right)$ is an attractive material in many fields because of its excellent mechanical, thermal, optical, and electrical characteristics. ${ }^{16,17} \mathrm{ZrO}_{2}$ can present three polymorphic crystalline structures, that is, monoclinic (below 1170 ${ }^{\circ} \mathrm{C}$ ), tetragonal $\left(1170-2370{ }^{\circ} \mathrm{C}\right.$ ), and cubic (above $\left.2370{ }^{\circ} \mathrm{C}\right) .{ }^{17}$ Recently, there were many efforts devoted to fabricate $\mathrm{ZrO}_{2}-$ $\mathrm{CNT}$ nanocomposites in hopes of broadening the applications of $\mathrm{ZrO}_{2}{ }^{18-23}$ For example, $\mathrm{ZrO}_{2}-\mathrm{CNT}$ nanocomposite prepared by a hydrothermal method was found to be a good biocompatible matrix for protein immobilization. ${ }^{18}$ In addition, it was also found that the Pt catalyst supported by $\mathrm{ZrO}_{2}-\mathrm{CNT}$ nanocomposites exhibited significantly improved catalytic activity toward methanol and ethanol oxidation in direct methanol and ethanol fuel cells compared with that supported by either CNTs or commercial C. ${ }^{19,20}$ Moreover, CNT transistors integrated with high-k $\mathrm{ZrO}_{2}$ were applied as advanced gate dielectrics, which will be crucial for future molecular electronics. ${ }^{21}$ Thus, $\mathrm{ZrO}_{2}-\mathrm{CNT}$ nanocomposites are promising for applications in fuel cells, batteries, electronics devices, and chemical sensors.

To fulfill these applications, it is of great importance to controllably synthesize $\mathrm{ZrO}_{2}-\mathrm{CNT}$ nanocomposites. In previous studies, the fabrication of $\mathrm{ZrO}_{2}-\mathrm{CNT}$ nanocomposites was mainly achieved by solution-based methods. ${ }^{16,17,23-25}$ For example, Sun et al. ${ }^{23}$ synthesized $\mathrm{ZrO}_{2}-\mathrm{CNT}$ nanocomposites via decomposition of $\mathrm{Zr}\left(\mathrm{NO}_{3}\right)_{4} \cdot 8 \mathrm{H}_{2} \mathrm{O}$ in supercritical carbon dioxide-ethanol solution with dispersed CNTs at relatively low temperatures. Shan and $\mathrm{Gao}^{24}$ prepared $\mathrm{ZrO}_{2}-$ CNT nanocomposites with phase-controlled $\mathrm{ZrO}_{2}$ by hydrothermal treatment of CNTs in $\mathrm{ZrOCl}_{2} \cdot 8 \mathrm{H}_{2} \mathrm{O}$ aqueous solution at $150{ }^{\circ} \mathrm{C}$. Most of these studies were focused on controlling the phase ${ }^{17,24,25}$ or morphology ${ }^{16}$ of $\mathrm{ZrO}_{2}$ coated on CNTs, and the CNTs used in these studies required a pretreatment process by either covalent ${ }^{26}$ or noncovalent ${ }^{14,27}$ methods to functionalize their inert surface. The pretreatment might adversely affect the inherent properties of the CNTs.

Herein, we developed an alternative approach to synthesize $\mathrm{ZrO}_{2}-\mathrm{CNT}$ nanocomposites. This approach features crystal-

Received: March 25, 2012

Revised: May 18, 2012

Published: June 4, 2012 


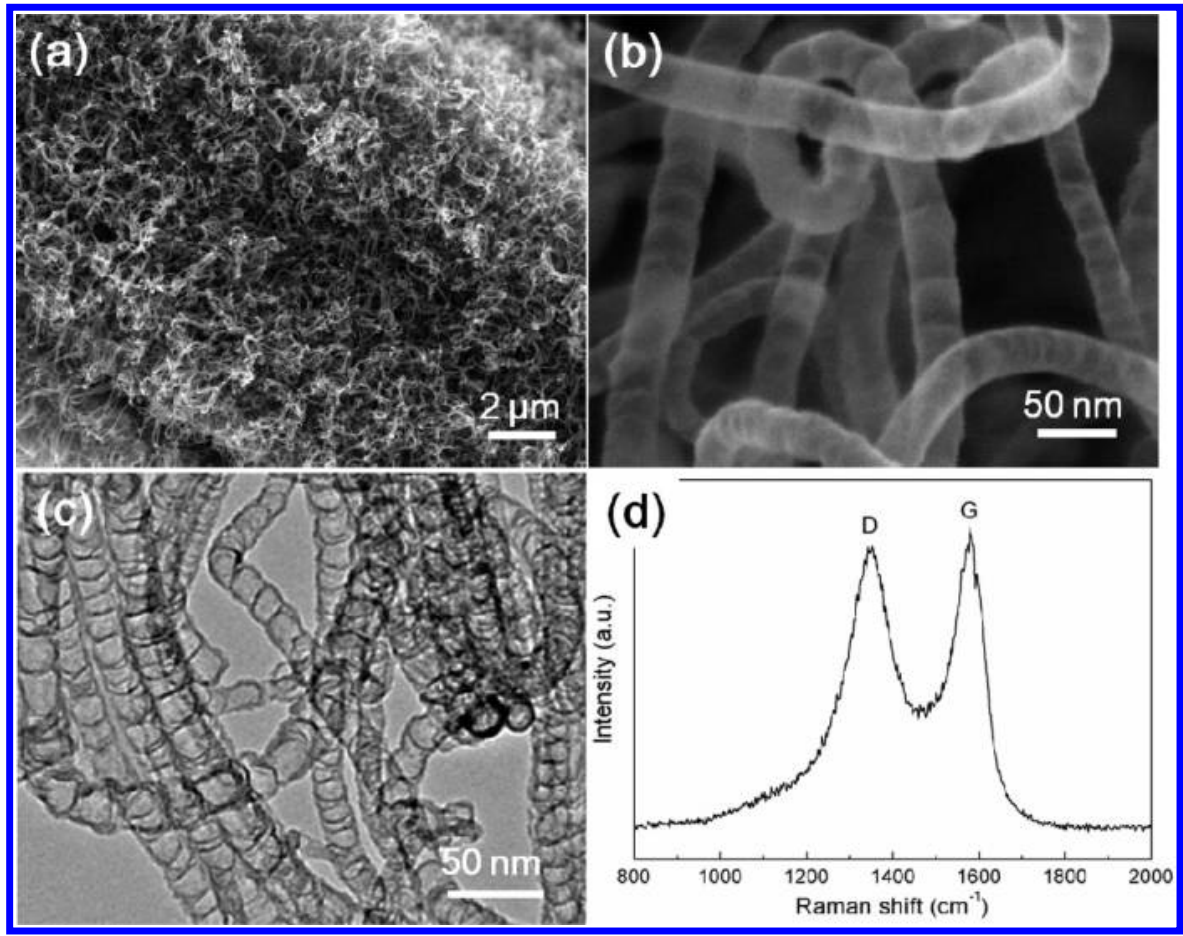

Figure 1. (a, b) SEM images, (c) TEM image, and (d) Raman spectrum of NCNTs synthesized by the CVD method.

linity-controlled deposition of $\mathrm{ZrO}_{2}$ tubular films directly on nitrogen-doped carbon nanotubes (NCNTs) using atomic layer deposition (ALD), which has been our research interest both in synthesizing ${ }^{28-32}$ and in applications. ${ }^{33,34}$ ALD is a unique technique which allows the deposition of conformal and uniform thin films via sequential and self-terminating gas-solid reactions with controlled film thickness at atomic level. ${ }^{35,36}$ The coating of $\mathrm{ZrO}_{2}$ on CNTs was previously achieved with the use of $\mathrm{ZrCl}_{4}$ and $\mathrm{H}_{2} \mathrm{O}$ as precursors, whereas detailed studies are still lacking. ${ }^{21}$ Moreover, the use of $\mathrm{ZrCl}_{4}$ as $\mathrm{Zr}$ precursor may constrain the application of $\mathrm{ZrO}_{2}$ because $\mathrm{ZrCl}_{4}$ suffers from serious processing problems including the corrosion of deposition system caused by $\mathrm{HCl}$ generated during the reaction, high risk of small particles being transported into substrates, and high evaporation temperature $\left(165^{\circ} \mathrm{C}\right)$ because of its low volatility. ${ }^{37}$ In comparison, tetrakis(dimethylamido)zirconium(IV) $\left[\mathrm{Zr}\left(\mathrm{NMe}_{2}\right)_{4}\right]$ as an ALD precursor has several advantages over $\mathrm{ZrCl}_{4}$, such as sufficient volatility, thermal stability, and high reactivity to a hydroxylated surface. ${ }^{38-40}$ Using $\mathrm{Zr}\left(\mathrm{NMe}_{2}\right)_{4}$ and $\mathrm{H}_{2} \mathrm{O}$ as ALD precursors, for example, $\mathrm{ZrO}_{2}$ films were successfully deposited on $\mathrm{Si}$ and glassy carbon substrates with a growth per cycle (GPC) of $0.096 \pm 0.002 \mathrm{~nm}$ in the range of $50-250{ }^{\circ} \mathrm{C} .^{38,39}$ It was reported that the ALD of $\mathrm{ZrO}_{2}\left(\mathrm{ALD}-\mathrm{ZrO}_{2}\right)$ using these two precursors consists of two half reactions ${ }^{38}$

$$
\begin{aligned}
& \|-\mathrm{OH}+\mathrm{Zr}\left(\mathrm{NMe}_{2}\right)_{4}(\mathrm{~g}) \\
& \quad \rightarrow \|-\mathrm{OZr}\left(\mathrm{NMe}_{2}\right)_{3}+\mathrm{C}_{2} \mathrm{H}_{7} \mathrm{~N}(\mathrm{~g}) \\
& \left\|-\mathrm{NMe}_{2}+\mathrm{H}_{2} \mathrm{O}(\mathrm{g}) \rightarrow\right\|-\mathrm{OH}+\mathrm{C}_{2} \mathrm{H}_{7} \mathrm{~N}(\mathrm{~g})
\end{aligned}
$$

where II represents substrate surface and $(\mathrm{g})$ denotes vapor species. Therefore, in this work, $\mathrm{Zr}\left(\mathrm{NMe}_{2}\right)_{4}$ and $\mathrm{H}_{2} \mathrm{O}$ were employed as precursors for $\mathrm{ALD}-\mathrm{ZrO}_{2}$. The NCNTs were homemade and were suitable for ALD processes without any additional pretreatment steps. $^{29,31}$ In summary, this work describes the uniform deposition of $\mathrm{ALD}-\mathrm{ZrO}_{2}$ films on NCNTs with not only precisely controlled thickness at nanoscale level but also highly tunable crystallinity from amorphous to crystalline. In addition, the growth process of ALD- $\mathrm{ZrO}_{2}$ on NCNTs was explored, and the growth mechanisms of ALD- $\mathrm{ZrO}_{2}$ on NCNTs were proposed. This kind of $\mathrm{ZrO}_{2}-\mathrm{NCNT}$ nanocomposites synthesized by ALD may find many potential applications, such as fuel cells, batteries, electronics, and gas sensors.

\section{EXPERIMENTAL SECTION}

2.1. Synthesis of NCNTs. NCNTs were prepared by a chemical vapor deposition (CVD) method using melamine $\left(\mathrm{C}_{3} \mathrm{H}_{6} \mathrm{~N}_{6}, 99+\%\right.$, Aldrich) as the only source for both carbon and nitrogen. The substrate used for the growth of NCNTs was a carbon paper, which had been sequentially coated by an aluminum film (30 nm in thickness) and an iron film (5 nm in thickness) in a sputtering system. The aluminum film as a buffer layer could improve the quality and growth rate of NCNTs, while the iron film could catalyze the growth of NCNTs. ${ }^{41}$ In a typical process, NCNTs were grown by the pyrolysis of melamine at $800{ }^{\circ} \mathrm{C}$ using argon (99.999\% in purity) as a protective and carrier gas. More details can be found in our previous work. ${ }^{42}$

2.2. $\mathrm{ZrO}_{2}-\mathrm{NCNTs}$ by ALD. The deposition of $\mathrm{ZrO}_{2}$ on NCNTs was achieved by alternatively supplying $\mathrm{Zr}\left(\mathrm{NMe}_{2}\right)_{4}$ (99\%, STREM) and deionized water $\left(\mathrm{H}_{2} \mathrm{O}\right)$ into a commercial ALD reactor (Savannah 100, Cambridge Nanotech Inc., United States). $\mathrm{Zr}\left(\mathrm{NMe}_{2}\right)_{4}$ was heated to $75{ }^{\circ} \mathrm{C}$, while water was kept at room temperature. In that case, sufficient precursor vapors could be supplied for the deposition of $\mathrm{ZrO}_{2}$. Additionally, the delivery lines were heated to $100{ }^{\circ} \mathrm{C}$ to prevent the precursors from condensation. Nitrogen gas ( $99.999 \%$ in purity) was used as a carrier gas with a flow rate of $20 \mathrm{sccm}$, and the ALD reactor was maintained at a low level of base pressure (typically $0.3-$ 0.4 Torr) by a vacuum pump (Pascal 2005 I, Adixen). One 

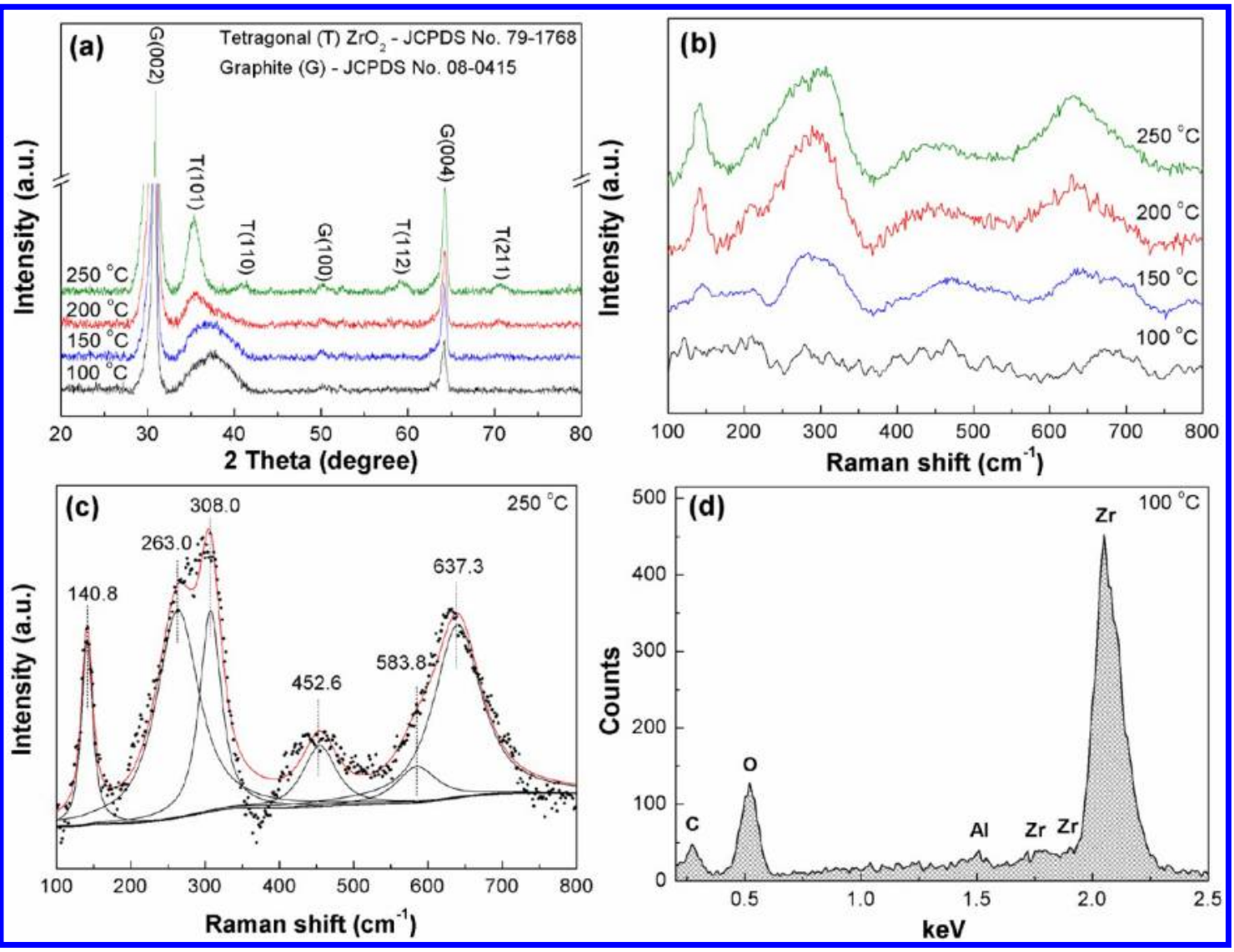

Figure 2. XRD patterns (a) and Raman spectra (b) of 100-cycle $\mathrm{ZrO}_{2}-\mathrm{NCNTs}$ prepared at 250, 200, 150, and $100{ }^{\circ} \mathrm{C}$. (c) Deconvolution of Raman spectrum of 100 -cycle $\mathrm{ZrO}_{2}-\mathrm{NCNTs}$ prepared at $250{ }^{\circ} \mathrm{C}$. (d) EDS spectrum of 100 -cycle $\mathrm{ZrO}_{2}-\mathrm{NCNTs}$ prepared at $100{ }^{\circ} \mathrm{C}$.

ALD cycle was executed with the following six steps: (1) a supply of $\mathrm{Zr}\left(\mathrm{NMe}_{2}\right)_{4}$ with a $t_{1}$ pulse time; (2) a 3.0 s extended exposure of $\mathrm{Zr}\left(\mathrm{NMe}_{2}\right)_{4}$ to NCNTs; (3) a purging of oversupplied $\mathrm{Zr}\left(\mathrm{NMe}_{2}\right)_{4}$ and any byproducts with a $t_{2}$ purge time; (4) a supply of $\mathrm{H}_{2} \mathrm{O}$ with a $t_{3}$ pulse time; (5) a $3.0 \mathrm{~s}$ extended exposure of $\mathrm{H}_{2} \mathrm{O}$ to NCNTs; (6) a purging of excess $\mathrm{H}_{2} \mathrm{O}$ and any byproducts with a $t_{4}$ purge time. In short, the deposition procedure can be described as $t_{1}-t_{2}-t_{3}-t_{4} . \mathrm{ZrO}_{2}$ was deposited on NCNTs by repeating the above ALD cycle at $250,200,150$, and $100{ }^{\circ} \mathrm{C}$, respectively.

2.3. Characterization of $\mathrm{ZrO}_{2}-\mathrm{NCNTs}$. The morphology and structure of as-synthesized $\mathrm{ZrO}_{2}-\mathrm{NCNT}$ nanocomposites were characterized by a field-emission scanning electron microscope (SEM, Hitachi S4800) equipped with energydispersive $\mathrm{X}$-ray spectroscopy (EDS), transmission electron microscope (TEM, Hitachi H-7000), high-resolution TEM (HRTEM, JEOL 2010 FEG), micro-X-ray diffraction (XRD, Bruker D8, Co $\mathrm{K} \alpha$ source, $\lambda=1.7892 \AA$ ), and Raman spectrometer (HORIBA Scientific LabRAW HR800) with an incident laser beam of $532.4 \mathrm{~nm}$.

\section{RESULTS AND DISCUSSION}

3.1. Results. Figure $1(a-c)$ shows the morphology and structure of NCNTs prepared by the CVD method. From Figure 1 (a, b), it can be seen that the carbon paper was totally covered by high-density NCNTs with diameters in a range of 20-35 nm. The TEM image in Figure 1c indicates that the synthesized NCNTs possess a typical bamboolike structure, which is induced by nitrogen doping in the hexagonal framework of carbon layers. ${ }^{42,43}$ The Raman spectrum of the
NCNTs shows two first-order Raman peaks centered at $\sim 1342$ $\mathrm{cm}^{-1}$ and $\sim 1582 \mathrm{~cm}^{-1}$, which are so-called D-band and G-band, respectively, as seen in Figure $1 \mathrm{~d}$. The intensity ratio between D-band and G-band $\left(I_{\mathrm{D}} / I_{\mathrm{G}}\right)$ is calculated to be 0.94 for the NCNTs revealing its high degree of disorder because of nitrogen doping. ${ }^{43}$

To find out the conditions for saturated growth of ALD$\mathrm{ZrO}_{2}$, the pulse time and purge time for both precursors were optimized. The deposition temperature was chosen to be 200 ${ }^{\circ} \mathrm{C}$ using $\mathrm{Zr}\left(\mathrm{NMe}_{2}\right)_{4}$ and $\mathrm{H}_{2} \mathrm{O}$ as precursors. ${ }^{38}$ The optimization was carried out by changing one parameter at a time while keeping the others constant. The results indicated that a $0.5 \mathrm{~s}$ pulse of $\mathrm{Zr}\left(\mathrm{NMe}_{2}\right)_{4}$ and a $1.0 \mathrm{~s}$ pulse of $\mathrm{H}_{2} \mathrm{O}$ are sufficient to realize saturated growth of ALD- $\mathrm{ZrO}_{2}$ thin film on NCNTs (Figure SI-1 of the Supporting Information). The purge time required is at least $30 \mathrm{~s}$ in order to avoid CVD-like growth of $\mathrm{ZrO}_{2}$ (Figure SI-2a, b of the Supporting Information) and to achieve uniform deposition of ALD- $\mathrm{ZrO}_{2}$ thin film (Figure SI-2c, $\mathrm{d}$ of the Supporting Information). A prolonged purge time had no obvious effect on the thickness and uniformity of $\mathrm{ALD}-\mathrm{ZrO}_{2}$ thin film (Figure SI-2e, $\mathrm{f}$ of the Supporting Information). Therefore, all the ALD- $\mathrm{ZrO}_{2}$ was conducted with the procedure of $0.5 \mathrm{~s}, 30 \mathrm{~s}, 1 \mathrm{~s}, 30 \mathrm{~s}$.

3.1.1. Crystalline Development of $A L D-\mathrm{ZrO}_{2}$. The structural phases of 100 -cycle ALD- $\mathrm{ZrO}_{2}$ prepared at 250, 200, 150, and $100{ }^{\circ} \mathrm{C}$ were identified by XRD and Raman techniques, and the results are presented in Figure 2. Figure 2a shows the XRD patterns of 100 -cycle $\mathrm{ZrO}_{2}-\mathrm{NCNT}$ prepared at 250, 200, 150, and $100{ }^{\circ} \mathrm{C}$. It can be seen that all samples exhibit two strong peaks at $30^{\circ}$ and $64^{\circ}$ and a weak one at $50^{\circ}$, which are indexed 

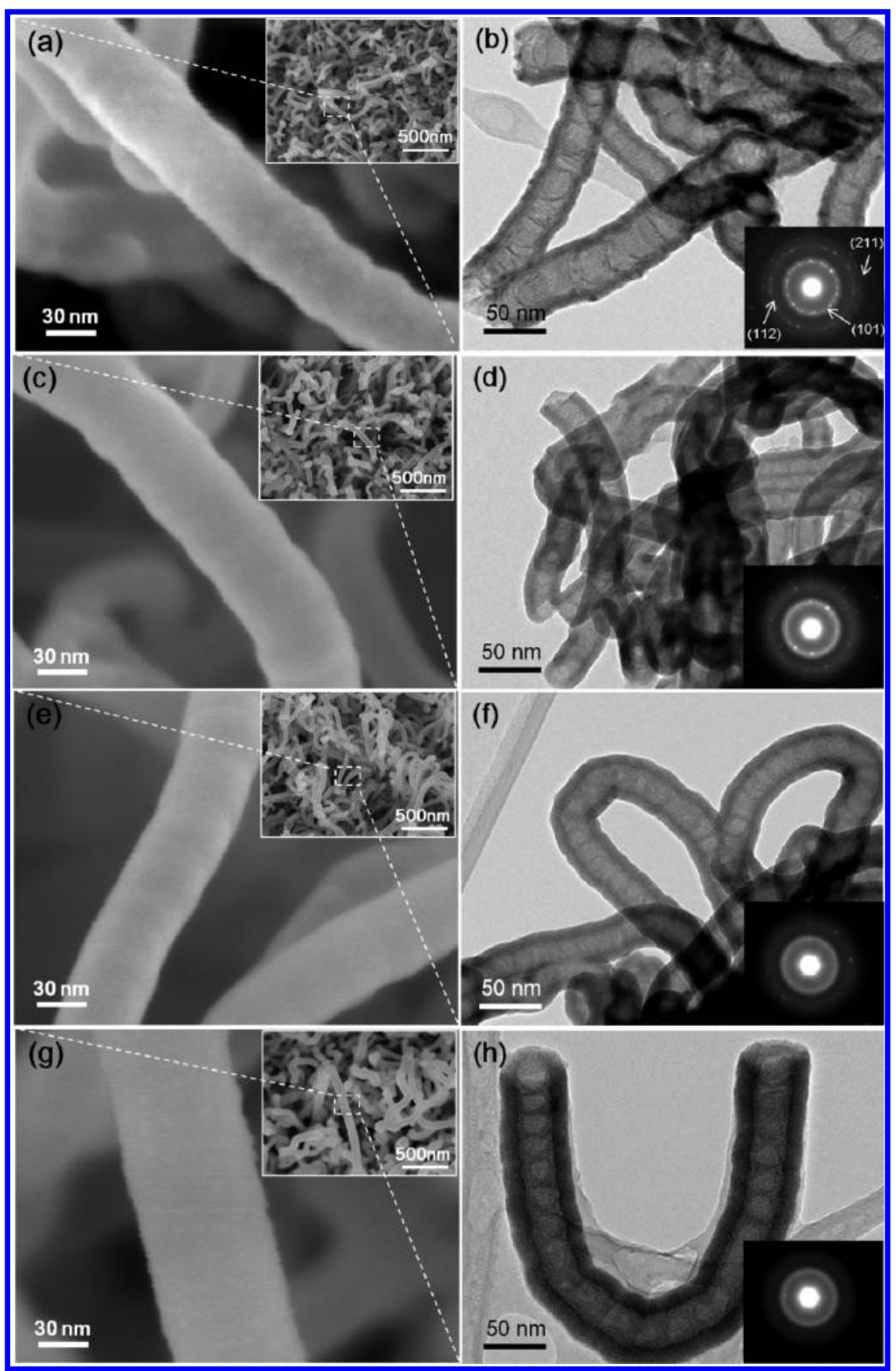

Figure 3. SEM (a, c, e, g) and TEM (b, d, f, h) images of 100 -cycle $\mathrm{ZrO}_{2}-\mathrm{NCNTs}$ prepared at $250{ }^{\circ} \mathrm{C}(\mathrm{a}, \mathrm{b}), 200{ }^{\circ} \mathrm{C}(\mathrm{c}, \mathrm{d}), 150{ }^{\circ} \mathrm{C}(\mathrm{e}, \mathrm{f})$, and 100 ${ }^{\circ} \mathrm{C}(\mathrm{g}, \mathrm{h})$. (Inset in each TEM image corresponds to its SAED pattern.)

as (002), (004), and (100) planes of graphite (JCPDS PDF No. 08-0415), respectively. They are apparently induced by the carbon paper and NCNTs grown on it. For the $\mathrm{ZrO}_{2}-\mathrm{NCNTs}$ prepared at $250{ }^{\circ} \mathrm{C}$, the other peaks located at $36^{\circ}, 41^{\circ}, 59^{\circ}$, and $71^{\circ}$ are well consistent with the planes of (101), (110), (112), and (211) of tetragonal $\mathrm{ZrO}_{2}$ (JCPDS PDF No. 791768), respectively. The four peaks could be also assigned to cubic $\mathrm{ZrO}_{2}$, however, the existence of which is excluded later by Raman examination. With a decrease in deposition temperature, the peak of (101) plane of tetragonal $\mathrm{ZrO}_{2}$ shifts to higher degrees and becomes broader in terms of half-width. In the meantime, the other peaks belonging to tetragonal $\mathrm{ZrO}_{2}$ become weaker in intensity. They totally disappear in the $\mathrm{ZrO}_{2}-\mathrm{NCNT}$ prepared at $100{ }^{\circ} \mathrm{C}$. The $\mathrm{XRD}$ results indicate that the $\mathrm{ALD}-\mathrm{ZrO}_{2}$ experienced a gradual decrease in its crystallinity when decreasing the deposition temperature. Raman spectroscopy was carried out on the above samples in a region of $100-800 \mathrm{~cm}^{-1}$, and the results are presented in Figure $2 b$, c. From Figure 2b, it can be seen that Raman spectra are approximately the same for $\mathrm{ZrO}_{2}-\mathrm{NCNT}$ prepared at 250, 200, and $150{ }^{\circ} \mathrm{C}$. Deconvolution of the Raman spectrum for $\mathrm{ZrO}_{2}-\mathrm{NCNTs}$ prepared at $250{ }^{\circ} \mathrm{C}$ reveals six peaks located at 140.8, 263.0, 308.0, 452.6, 538.8, and $637.3 \mathrm{~cm}^{-1}$ (Figure 2c), which can be clearly assigned to the six Raman active modes $\left(\mathrm{A}_{1 \mathrm{~g}}+2 \mathrm{~B}_{1 \mathrm{~g}}+3 \mathrm{E}_{\mathrm{g}}\right)$ of tetragonal $\mathrm{ZrO}_{2}{ }^{44,45}$ Similar results were also obtained for $\mathrm{ZrO}_{2}-\mathrm{NCNTs}$ prepared at 200 and $150{ }^{\circ} \mathrm{C}$. For the $\mathrm{ZrO}_{2}-\mathrm{NCNT}$ s prepared at $100{ }^{\circ} \mathrm{C}$, however, broad peaks with weak intensities are observed in their Raman 


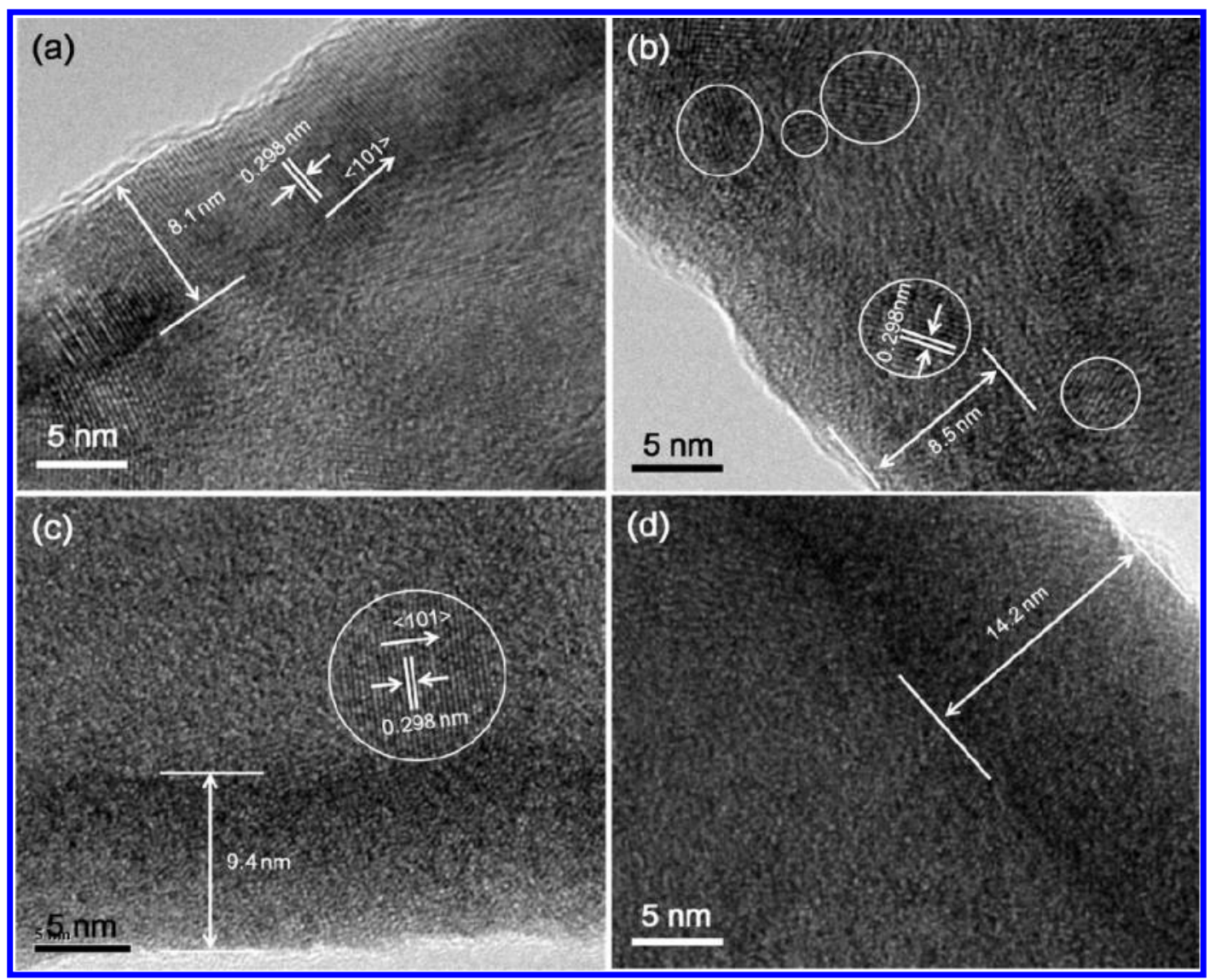

Figure 4. HRTEM images of 100 -cycle $\mathrm{ZrO}_{2}-\mathrm{NCNT}$ prepared at (a) $250{ }^{\circ} \mathrm{C}$, (b) $200{ }^{\circ} \mathrm{C}$, (c) $150{ }^{\circ} \mathrm{C}$, and (d) $100{ }^{\circ} \mathrm{C}$.

spectrum (Figure $2 b$ ) from which it is hard to identify the phase of the deposited $\mathrm{ZrO}_{2}$. This kind of Raman spectrum is probably due to the extremely limited long-range periodicity of $\mathrm{ZrO}_{2}$ prepared at such low temperature. ${ }^{45}$ Nonetheless, EDS analysis verified the presence of $\mathrm{Zr}$ and $\mathrm{O}$ elements in the $\mathrm{ZrO}_{2}-\mathrm{NCNT}$ s prepared at $100{ }^{\circ} \mathrm{C}$ as seen in Figure $2 \mathrm{~d}$.

Tetragonal $\mathrm{ZrO}_{2}$ is generally stable at high temperatures $\left(1170-2370{ }^{\circ} \mathrm{C}\right),{ }^{17}$ while in our case, it was not only prepared at temperatures below $250{ }^{\circ} \mathrm{C}$ but was also stable at room temperature. The occurrence of tetragonal $\mathrm{ZrO}_{2}$ at low temperatures has been reported previously. ${ }^{46-49}$ Earlier studies believed that the low-temperature tetragonal $\mathrm{ZrO}_{2}$ should be ascribed to grain size effect, that is, $\mathrm{ZrO}_{2}$ with small size and high surface area can provide high surface energy to stabilize metastable tetragonal $\mathrm{ZrO}_{2}$ at low temperatures. ${ }^{48,49}$ In this work, NCNTs acted as promising ALD $-\mathrm{ZrO}_{2}$ substrate with high surface area and high surface energy, which in return help the stabilization of tetragonal $\mathrm{ZrO}_{2}$ at temperatures below 250 ${ }^{\circ} \mathrm{C}$.

The morphologies of 100 -cycle ALD- $\mathrm{ZrO}_{2}$ on NCNTs prepared at $250,200,150$, and $100{ }^{\circ} \mathrm{C}$ were observed by SEM and TEM, and the results are presented in Figure 3. From Figure 3 (a, c, e, g), it can be clearly seen that NCNTs are homogeneously coated with $\mathrm{ZrO}_{2}$ tubular thin films at deposition temperatures of $250,200,150$, and $100{ }^{\circ} \mathrm{C}$. TEM observation reveals that these $\mathrm{ZrO}_{2}$ thin films are extremely uniform and conformal on NCNTs in all the cases as shown in Figure 3 (b, d, f, h). Furthermore, selected area electron diffraction (SAED) was employed and the crystallinity of ALD$\mathrm{ZrO}_{2}$ was revealed as shown by the insets in Figure 3 (b, d, f, h). For the $\mathrm{ZrO}_{2}-\mathrm{NCNTs}$ prepared at $250{ }^{\circ} \mathrm{C}$, the SAED diffraction rings can be indexed as (101), (112), and (211) planes of tetragonal $\mathrm{ZrO}_{2}$ indicating its polycrystalline feature (see the inset in Figure $3 b$ ). From Figure $3 d$ and $f$, it can be clearly seen that the diffraction rings become more diffusive with the decreasing deposition temperature. In the case of 100 ${ }^{\circ} \mathrm{C}$, only diffusive rings are observed as shown by the inset in Figure $3 \mathrm{~h}$ manifesting that the $\mathrm{ALD}-\mathrm{ZrO}_{2}$ consists of only the amorphous phase. The SAED results indicate that ALD- $\mathrm{ZrO}_{2}$ on NCNTs is temperature-dependent in the crystallinity. In particular, the information extracted from SAED and XRD results (see Figure $2 \mathrm{a}$ ) is consistent with the crystallinity of the $\mathrm{ALD}-\mathrm{ZrO}_{2}$ prepared at different deposition temperatures.

The microstructures of 100 -cycle ALD- $\mathrm{ZrO}_{2}$ were further investigated using HRTEM as shown in Figure 4. Figure 4a reveals that $\mathrm{ALD}-\mathrm{ZrO}_{2}$ thin film is fully crystalline at $250{ }^{\circ} \mathrm{C}$, and the interplanar spacing of $0.298 \mathrm{~nm}$ (as marked in Figure $4 a)$ is consistent with the spacing distance between (101) planes of tetragonal $\mathrm{ZrO}_{2}$. In the case of $200{ }^{\circ} \mathrm{C}$, the $\mathrm{ZrO}_{2}$ thin film is composed of both crystalline nanoparticles and amorphous layers. These nanoparticles with tetragonal $\mathrm{ZrO}_{2}$ phase randomly distribute in the matrix of the amorphous $\mathrm{ZrO}_{2}$ as shown in Figure 4b. At the lower deposition temperature of $150{ }^{\circ} \mathrm{C}$ as shown in Figure 4c, it is found that these nanoparticles become sparse, and the matrix of amorphous $\mathrm{ZrO}_{2}$ layers takes the dominance. At the lowest deposition temperature of $100{ }^{\circ} \mathrm{C}$ as shown in Figure $4 \mathrm{~d}$, only amorphous $\mathrm{ZrO}_{2}$ thin film can be identified. On the basis of the above results, it can be concluded that the crystallinity of ALD- $\mathrm{ZrO}_{2}$ is temperature-dependent, that is, the deposited $\mathrm{ZrO}_{2}$ shows crystalline tetragonal phase at $250{ }^{\circ} \mathrm{C}$, amorphous phase at 100 
${ }^{\circ} \mathrm{C}$, and a mixture of the former two in the range of 200-150 ${ }^{\circ} \mathrm{C}$.

During ALD processes, growth per cycle (GPC) is an important measure to evaluate the growth ability of desirable materials. In this work, the GPC of ALD- $\mathrm{ZrO}_{2}$ is calculated on the basis of the thickness of 100 -cycle ALD- $\mathrm{ZrO}_{2}$ thin films as shown in Figure 4. The GPC turns out to be 0.081, 0.085, 0.094 , and $0.142 \mathrm{~nm}$ at $250,200,150$, and $100{ }^{\circ} \mathrm{C}$, respectively (as plotted in Figure 5). It can be seen that the GPC of $\mathrm{ZrO}_{2}$

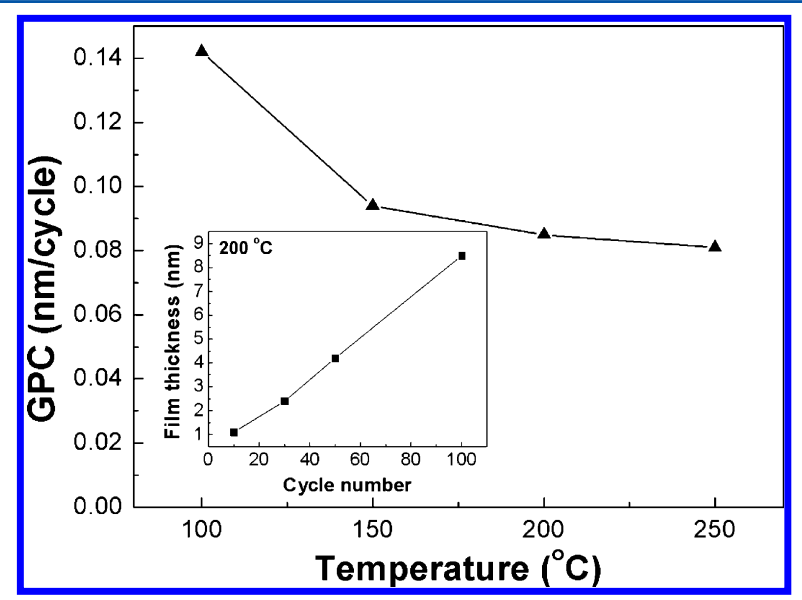

Figure 5. GPC of ALD-ZrO $\mathrm{Zr}_{2}$ on NCNTs as a function of deposition temperature (inset shows the thickness of $\mathrm{ZrO}_{2}$ thin film deposited at $200{ }^{\circ} \mathrm{C}$ as a function of ALD cycle number).

stays almost the same (around $0.085 \mathrm{~nm}$ ) from 250 to $150{ }^{\circ} \mathrm{C}$. One can also find that the GPC of $\mathrm{ZrO}_{2}$ at $100{ }^{\circ} \mathrm{C}(0.142 \mathrm{~nm})$ is apparently higher than those at the other temperatures.

3.1.2. Growth Process of $A L D-\mathrm{ZrO}_{2}$. The morphological evolution of ALD-ZrO $\mathrm{Zr}_{2}$ with ALD cycle was explored by SEM and HRTEM on the $\mathrm{ZrO}_{2}-\mathrm{NCNT}$ prepared at $200{ }^{\circ} \mathrm{C}$ and presented in Figure 6. Comparing Figure 6a with b, it is obvious that the surface of NCNTs is coated with many nanoparticles after only five ALD cycles. With the increase of ALD cycles, these nanoparticles start to coalesce (Figure6c) and eventually close into a uniform thin film after 30 cycles (Figure 6d). Further increasing ALD cycles leads to a thicker thin film with its uniformity maintained as shown in Figure 6e and Figure 3c. The morphological development of $\mathrm{ALD}-\mathrm{ZrO}_{2}$ was confirmed by HRTEM in Figure $6 \mathrm{f}-\mathrm{i}$. SEM observation on the $\mathrm{ZrO}_{2}-$ NCNTs prepared at 250,150 , and $100{ }^{\circ} \mathrm{C}$ indicates the similar growth process of $\mathrm{ALD}-\mathrm{ZrO}_{2}$ (Figures SI-4-6 of the Supporting Information). This phenomenon implies that the growth of $\mathrm{ALD}-\mathrm{ZrO}_{2}$ on NCNTs follows an island-growth mode at the very early stage and a layer-by-layer growth mode afterward.

HRTEM images of the $\mathrm{ZrO}_{2}-\mathrm{NCNT}$ s prepared at $200{ }^{\circ} \mathrm{C}$ after different ALD cycles also disclose the crystalline development of ALD- $\mathrm{ZrO}_{2}$ with ALD cycles as displayed in Figure $6 \mathrm{f}-\mathrm{i}$. Before 10 cycles, the $\mathrm{ALD}-\mathrm{ZrO}_{2}$ exhibits the amorphous state as seen in Figure 6f, g. After 30 cycles, the ALD- $\mathrm{ZrO}_{2}$ thin film is still dominated by the amorphous phase in the matrix of which some crystalline tetragonal $\mathrm{ZrO}_{2}$ nanoparticles (diameter around $1.5 \mathrm{~nm}$ ) can be found (Figure 6h). With increasing ALD cycles, these crystalline $\mathrm{ZrO}_{2}$ nanoparticles grow into bigger sizes, while the amorphous $\mathrm{ZrO}_{2}$ thin film becomes thicker as shown in Figure 6i and Figure 3d. Thus, at $200{ }^{\circ} \mathrm{C}$, the growth of amorphous $\mathrm{ZrO}_{2}$ continues during the whole ALD process, while nucleation and growth of crystalline $\mathrm{ZrO}_{2}$ start in the matrix of amorphous $\mathrm{ZrO}_{2}$ at the intermediate stage. The thicknesses of $\mathrm{ZrO}_{2}$ thin films after different ALD cycles at $200{ }^{\circ} \mathrm{C}$ are measured in Figure $6 \mathrm{~g}-\mathrm{i}$ and are plotted as a function of ALD cycle number (see the inset in Figure 5). In Figure 5, it can be clearly seen that the film thickness of ALD- $\mathrm{ZrO}_{2}$ shows an almost linear relationship with ALD cycles indicating the self-limiting growth of $\mathrm{ALD}-\mathrm{ZrO}_{2}$ on NCNTs.

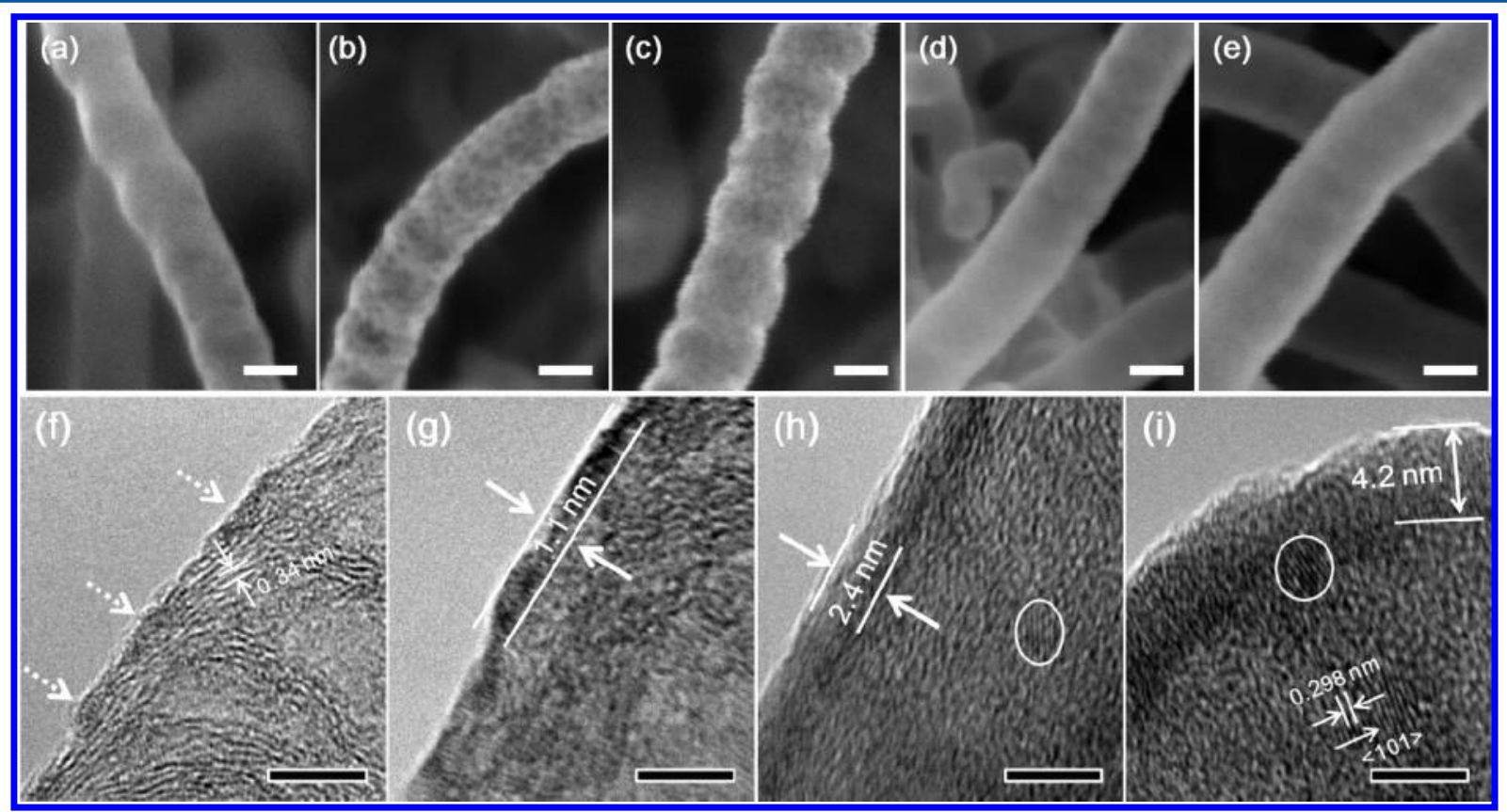

Figure 6. SEM images (a-e) of NCNTs without $\mathrm{ZrO}_{2}$ coating (a) and with $\mathrm{ZrO}_{2}$ coated at $200{ }^{\circ} \mathrm{C}$ after (b) 5 cycles, (c) 10 cycles, (d) 30 cycles, and (e) 50 cycles. HRTEM images (f-i) of NCNTs with $\mathrm{ZrO}_{2}$ coated at $200{ }^{\circ} \mathrm{C}$ after (f) 5 cycles, (g) 10 cycles, (h) 30 cycles, and (i) 50 cycles. The scale bar in a-e and $\mathrm{f}-\mathrm{i}$ represents 20 and $5 \mathrm{~nm}$, respectively. 
3.2. Discussion. From the results in section 3.1, one can easily see that ALD is distinguished as an innovative approach to synthesize $\mathrm{ZrO}_{2}-\mathrm{NCNT}$ nanocomposites in a wellcontrolled manner. The deposited $\mathrm{ZrO}_{2}$ thin films not only have highly tunable crystallinity from amorphous to crystalline but also have precisely controlled thickness at the atomic level. The first feature is mainly ascribed to temperature dependence of $\mathrm{ALD}-\mathrm{ZrO}_{2}$, whereas the second one results from the selfterminating nature of the ALD process. To better understand the characteristics of ALD- $\mathrm{ZrO}_{2}$, it is essentially important to clarify the influence of ALD process parameters, that is, the temperatures, substrates, and precursors, ${ }^{36}$ on the growth process, the GPC, and the crystallinity of $\mathrm{ALD}-\mathrm{ZrO}_{2}$ on NCNTs.

As disclosed in section 3.1.2, the growth of $\mathrm{ALD}-\mathrm{ZrO}_{2}$ on NCNTs follows an island-growth mode at the very early stage and a layer-by-layer growth mode after coalescence of these islands into a thin film in a temperature range of $100-250^{\circ} \mathrm{C}$. Interestingly, island growth of $\mathrm{ALD}-\mathrm{ZrO}_{2}$ was also previously observed on the substrate of hydrogen-terminated silicon using $\mathrm{ZrCl}_{4}$ and $\mathrm{H}_{2} \mathrm{O}$ as precursors. ${ }^{50-52}$ The reason for this undesired ALD process was attributed to the lack of functional $\mathrm{OH}$ adsorption sites on the hydrogen-passivated surfaces, and the island growth of $\mathrm{ZrO}_{2}$ started most likely at reactive defect sites of the substrate. ${ }^{50}$ Another study reported that $\mathrm{ZnO}$ nanoparticles could be grown on single-walled carbon nanotubes (SWCNTs) by ALD because of the sparse amount of defective sites on SWCNTs. ${ }^{53}$ Thus, the NCNT substrate in our case is believed to play a crucial role in determining the special growth process of ALD- $\mathrm{ZrO}_{2}$. As well-known, NCNTs are rich in surface defects induced by nitrogen doping. ${ }^{43}$ These $\mathrm{N}$-induced defects make the surface of NCNTs more reactive than that of CNTs and are thereby suitable for the direct growth of metal nanoparticles or nanowires on it. ${ }^{54,55}$ In our previous work, NCNTs were also employed as substrates for ALD-SnO ${ }_{2}$, and it was found that the surface defect sites, especially induced by pyridine-like $\mathrm{N}$ and graphite-like $\mathrm{N}$, were preferable sites for the nucleation of ALD-SnO ${ }_{2}{ }^{29}$ Therefore, in this work, it is reasonable to believe that $\mathrm{N}$-induced defect sites at the surface of NCNTs are responsible for the island growth of $\mathrm{ALD}-\mathrm{ZrO}_{2}$ at the very early stage. During the first cycle, $\mathrm{Zr}\left(\mathrm{NMe}_{2}\right)_{4}$ would chemically bond with these $\mathrm{N}$-induced defect sites, and then introduced $\mathrm{H}_{2} \mathrm{O}$ would react with the chemisorbed $\mathrm{Zr}\left(\mathrm{NMe}_{2}\right)_{4}$ via eq 2 generating $-\mathrm{OH}$ group terminated surface. ${ }^{38}$ The following ALD cycles would happen preferably on the existing $\mathrm{ZrO}_{2}$ surface via eq 1 and eq 2 sequentially leading to the island growth of $\mathrm{ALD}-\mathrm{ZrO}_{2}$ on NCNTs (see Figure $6 \mathrm{~b}, \mathrm{f}$ ). With a further increase of ALD cycles, these ALD- $\mathrm{ZrO}_{2}$ islands would grow in both vertical and lateral directions and finally would coalesce into a film (Figure $6 c, d, g, h)$. From this point on, the deposition of $\mathrm{ZrO}_{2}$ would occur on the film following a layer-by-layer growth mode (Figure 6e, i and Figure 3c, d). The thickness of $\mathrm{ZrO}_{2}$ thin film can be simply but accurately controlled by the number of ALD cycles (see Figure 5). In addition, it was demonstrated that chemically bonded N in NCNTs was thermally stable up to 800 ${ }^{\circ} \mathrm{C}$, ${ }^{56}$ and thus, the $\mathrm{N}$-induced defects on NCNTs in our case could be considered to remain unaffected by the temperature change from 100 to $250{ }^{\circ} \mathrm{C}$. Moreover, theoretical calculation ${ }^{57}$ showed that for $\mathrm{Zr}\left(\mathrm{NMe}_{2}\right)_{4}$, scission of metal-ligand bonds was more feasible than scission of $\mathrm{N}-\mathrm{C}$ bonds, and experiment study ${ }^{38}$ also indicated that the reaction of $\mathrm{Zr}\left(\mathrm{NMe}_{2}\right)_{4}$ and $\mathrm{H}_{2} \mathrm{O}$ in ALD would follow eqs 1 and 2 in the temperature range of
$100-250{ }^{\circ} \mathrm{C}$. Therefore, in our case, it can be considered that the temperature change does not affect the substrate and the reaction mechanism of precursors. At all deposition temperatures, $\mathrm{ALD}-\mathrm{ZrO}_{2}$ followed a similar growth process, that is, island growth mode at the very early stage and layer-by-layer growth mode after the close of these islands into a thin film as presented in Figure 6 and Figures SI-4-6 of the Supporting Information.

GPC is an important factor to measure the growth of ALD materials. In this work, the GPC of ALD- $\mathrm{ZrO}_{2}$ experienced an increase with decreasing temperature (see Figure 5). In particular, the GPC of $\mathrm{ALD}-\mathrm{ZrO}_{2}$ at $100{ }^{\circ} \mathrm{C}(0.142 \mathrm{~nm})$ is obviously higher than those at the other temperatures (around $0.085 \mathrm{~nm}$ ). Earlier studies have shown that the temperature could affect the GPC of ALD materials by having an effect on the number and types of reactive sites on the substrates and the preferred reaction mechanisms. ${ }^{36}$ As discussed above, the temperature change from $100-250{ }^{\circ} \mathrm{C}$ seemed not to affect the reaction mechanism of $\mathrm{Zr}\left(\mathrm{NMe}_{2}\right)_{4}$ and $\mathrm{H}_{2} \mathrm{O}$ in the ALD process. ${ }^{38,57}$ However, temperature does have an influence on the $-\mathrm{OH}$ groups, which were reactive sites for the ALD process and which were generated via eq 1 . Many previous studies ${ }^{58-60}$ have indicated that the number and types of hydroxyl groups were temperature-dependent, and high temperature could lead to dehydroxylation. During $\mathrm{ALD}-\mathrm{ZrO}_{2}$, the dehydroxylation of hydroxyl groups was described as follows: ${ }^{59}$

$$
2\|\mathrm{Zr}-\mathrm{OH} \rightarrow\| \mathrm{Zr}-\mathrm{O}-\mathrm{Zr} \|+\mathrm{H}_{2} \mathrm{O}
$$

Undoubtedly, this dehydroxylation would reduce the number of $-\mathrm{OH}$ groups and thereby would lead to a lower GPC at higher temperatures. Besides hydroxyl groups, physisorbed $\mathrm{Zr}\left(\mathrm{NMe}_{2}\right)_{4}$ and $\mathrm{H}_{2} \mathrm{O}$ are probably accountable for the higher GPC at 100 ${ }^{\circ} \mathrm{C}$. Ritala and Leskelä ${ }^{61}$ have shown that even at $500{ }^{\circ} \mathrm{C}$, the desorption of water from the hydroxyl-terminated surface could be slow enough, and long purge periods were needed. Hausmann et al. ${ }^{38}$ have proved that it took a much longer time to purge all surface-physisorbed $\mathrm{Zr}\left(\mathrm{NMe}_{2}\right)_{4}$ and $\mathrm{H}_{2} \mathrm{O}$ at lower temperatures. Therefore, given the same purge time in our case, there would be more surface-physisorbed $\mathrm{Zr}\left(\mathrm{NMe}_{2}\right)_{4}$ and $\mathrm{H}_{2} \mathrm{O}$ at lower temperatures, which would in return contribute to the growth of $\mathrm{ZrO}_{2}$. Surprisingly, the $\mathrm{ZrO}_{2}$ thin film at lower temperatures still maintained its uniformity as shown in Figure 3 and Figure 4. A prolonged purge time $(60 \mathrm{~s})$ for both precursors did not obviously affect the thickness of $\mathrm{ZrO}_{2}$ thin film (Figure SI-3 of the Supporting Information). Probably, a longer purge time than $60 \mathrm{~s}$ is required in order to avoid the surface-physisorbed precursors, but it will inevitably increase the preparation time of $\mathrm{ALD}-\mathrm{ZrO}_{2}$.

Besides growth mode and GPC, it is of great interest to explain the temperature dependence of the crystallinity of ALD$\mathrm{ZrO}_{2}$. In section 3.1.1, one can find that the deposition temperature is the only parameter that distinguishes the four samples in this work. Apparently, it plays a crucial role in determining the crystallinity of ALD-Z $\mathrm{ZO}_{2}$. A similar trend of crystallinity as a function of temperature was also previously reported in ALD-grown $\mathrm{ZrO}_{2}{ }^{38,62,63} \mathrm{TiO}_{2}{ }^{28,64} \mathrm{HfO}_{2}{ }^{65}$ and $\mathrm{SnO}_{2} \cdot{ }^{29,30}$ It was demonstrated that the temperature had strong effects on surface mobility of absorbed species, ${ }^{64,66}$ reaction mechanisms, ${ }^{29,30,63}$ and surface reactive sites ${ }^{29,63}$ thereby influencing the crystallinity of ALD-grown materials. High temperatures could enhance the surface mobility of absorbed species and could promote the ordering of the structure with minimum energy thus leading to the growth of crystallites. ${ }^{64,66}$ 
Meng and co-workers ${ }^{29,30}$ prepared phase-controlled ALD$\mathrm{SnO}_{2}$ using $\mathrm{SnCl}_{4}$ and $\mathrm{H}_{2} \mathrm{O}$ as precursors and proposed that the change of reaction mechanism from ligand exchange and chlorination with increasing temperatures was responsible for the phase transition from amorphous to crystalline. In addition, Scarel et al. ${ }^{63}$ suggested that the reaction mechanism between $-\mathrm{OH}$ species and $\mathrm{ZrCl}_{4}$ could be changed by the decreased density of $-\mathrm{OH}$ species with increasing temperatures thus affecting the crystallinity of deposited $\mathrm{ZrO}_{2}$. In our case, a higher temperature could help the mobilization of absorbed species and could enable the $\mathrm{Zr}$ and $\mathrm{O}$ ions to occupy the positions corresponding to the lowest free energy of the crystal $^{64}$ resulting in the crystalline phase of ALD-ZrO ${ }_{2}$ XRD (Figure 2a) and HRTEM (Figure 4) results indicated that the $\mathrm{ZrO}_{2}$ was preferentially oriented in the [101] direction, which seems to have the lowest free energy. Until now, there was no evidence showing that the reaction mechanism between $\mathrm{Zr}\left(\mathrm{NMe}_{2}\right)_{4}$ and $\mathrm{H}_{2} \mathrm{O}$ is temperature-dependent in the temperature range we employed as discussed previously. Nonetheless, the increase of temperature can modify the surface reactive sites via the dehydroxylation process described in eq 3 leading to reduced hydroxyl groups at the surface. This might be a reason accountable for the increased crystallinity of $\mathrm{ALD}-\mathrm{ZrO}_{2}$ with elevating temperatures. Unfortunately, there is to date little knowledge about the effect of decreased hydroxyl groups on the reaction mechanism and the crystallinity of ALD$\mathrm{ZrO}_{2}$ using $\mathrm{Zr}\left(\mathrm{NMe}_{2}\right)_{4}$ and $\mathrm{H}_{2} \mathrm{O}$ as precursors, and further investigations are needed. Another potential reason for $\mathrm{ZrO}_{2}$ being amorphous at lower temperatures is the residual dimethylamido ligand in the film, which could possibly prevent the crystallization of $\mathrm{ZrO}_{2}$. From the above discussion, one can clearly see the critical effect of temperature on the crystallinity of $\mathrm{ZrO}_{2}$ at a given ALD cycle. One the other hand, at a given temperature, the crystallinity of $\mathrm{ZrO}_{2}$ would be mainly related to the film thickness, and more crystalline $\mathrm{ZrO}_{2}$ could be found in the thicker film as disclosed in Figure 6. This phenomenon was also observed in previous studies and could be explained as follows. ${ }^{39,67}$ At a given temperature, the nucleation events of crystalline $\mathrm{ZrO}_{2}$ were distributed randomly over the surface of the substrate during each ALD cycle. The increase of ALD cycles could lead to the nucleation of more crystalline $\mathrm{ZrO}_{2}$ nuclei in the thicker film. Once crystalline $\mathrm{ZrO}_{2}$ nuclei formed, the following ALD cycle would contribute further mass to the nuclei resulting in the growth of crystalline $\mathrm{ZrO}_{2}$. Therefore, the thicker film induced by more ALD cycles contained more crystalline $\mathrm{ZrO}_{2}$ than the thinner film did. In this work, no more than 100 ALD cycles of $\mathrm{ZrO}_{2}$ were used. A further increase of ALD cycles could lead to the change of $\mathrm{ZrO}_{2}$ in its crystallinity (amorphous or crystalline), ${ }^{33,67}$ its phase (tetragonal, cubic, or monoclinic), ${ }^{67}$ or even its surface roughness. ${ }^{33}$

Figure 7 presents a schematic diagram to summarize the crystallite and morphological developments of $\mathrm{ALD}-\mathrm{ZrO}_{2}$ at temperatures between 100 and $250{ }^{\circ} \mathrm{C}$. $\mathrm{ZrO}_{2}$ exhibits only amorphous phase at $100{ }^{\circ} \mathrm{C}$, whereas it exhibits only crystalline phase at $250^{\circ} \mathrm{C}$. At intermediate temperature $\left(150-200{ }^{\circ} \mathrm{C}\right)$, the growth of amorphous $\mathrm{ZrO}_{2}$ starts at the very beginning and continues during the whole process, while crystalline $\mathrm{ZrO}_{2}$ nucleates and grows only during the intermediate process. Crystalline $\mathrm{ZrO}_{2}$ was embedded in the matrix of amorphous $\mathrm{ZrO}_{2}$ and did not affect the uniformity of the $\mathrm{ZrO}_{2}$ thin film. At all temperatures, the growth of ALD- $\mathrm{ZrO}_{2}$ follows an islandgrowth mode at the very early stage and a layer-by-layer growth mode after the coalescence of these islands into a film.

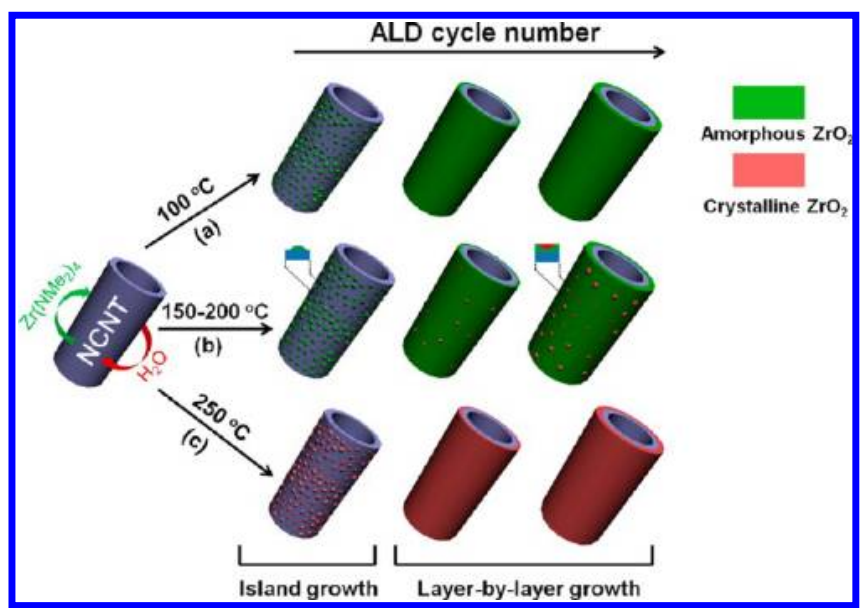

Figure 7. Schematic diagram for the growth mechanism of ALD- $\mathrm{ZrO}_{2}$ on NCNTs at (a) $100{ }^{\circ} \mathrm{C}$, (b) $150-200{ }^{\circ} \mathrm{C}$, and (c) $250{ }^{\circ} \mathrm{C}$.

\section{CONCLUSIONS}

In this work, $\mathrm{ZrO}_{2}-\mathrm{NCNT}$ nanocomposites were successfully prepared by ALD at deposition temperatures from 100 to 250 ${ }^{\circ} \mathrm{C}$. The results showed that the crystallinity of $\mathrm{ZrO}_{2}$ thin film experienced a gradual decrease with the decrease of temperature. The deposition temperature of $250{ }^{\circ} \mathrm{C}$ resulted in pure crystalline $\mathrm{ZrO}_{2}$, while $100^{\circ} \mathrm{C}$ leaded to pure amorphous $\mathrm{ZrO}_{2}$. Mixed phases of crystalline and amorphous $\mathrm{ZrO}_{2}$ appeared in $\mathrm{ZrO}_{2}-\mathrm{NCNT}$ between 150 and $200{ }^{\circ} \mathrm{C}$. The $\mathrm{ZrO}_{2}$ thin film was very uniform and conformal. The GPC of $\mathrm{ZrO}_{2}$ was 0.081 , $0.085,0.094$, and $0.142 \mathrm{~nm}$ at $250,200,150$, and $100{ }^{\circ} \mathrm{C}$, respectively. At all deposition temperatures, the growth of $\mathrm{ZrO}_{2}$ followed island-growth mode during the early stage and layerby-layer growth mode after the coalescence of the islands into a film. It is expected that such $\mathrm{ZrO}_{2}-\mathrm{NCNT}$ nanocomposites have great potential for various applications in fuel cells, batteries, electronics devices, and chemical sensors.

\section{ASSOCIATED CONTENT}

\section{S Supporting Information}

SEM and TEM images of 50-cycle $\mathrm{ZrO}_{2}-\mathrm{NCNT}$ prepared at 100 and $200{ }^{\circ} \mathrm{C}$; SEM images of $\mathrm{ZrO}_{2}-\mathrm{NCNTs}$ prepared at 250, 150, and $100{ }^{\circ} \mathrm{C}$ with different ALD cycles. This material is available free of charge via the Internet at http://pubs.acs.org.

\section{AUTHOR INFORMATION}

\section{Corresponding Author}

*Tel: +1 5196612111 x87759; fax: + 1519661 3020; e-mail: xsun@eng.uwo.ca (X.S.).

\section{Notes}

The authors declare no competing financial interest.

\section{ACKNOWLEDGMENTS}

This research was supported by General Motors of Canada, Natural Sciences and Engineering Research Council of Canada (NSERC), Canada Fundation for Innovation (CFI), Ontario Research Fund (ORF), Ontario Early Researcher Award (ERA), and University of Western Ontario. The authors also would like to thank Fred Pearson at Mcmaster University for his help on HRTEM.

\section{REFERENCES}

(1) Iijima, S. Nature 1991, 354, 56-58. 
(2) Dresselhaus, M.; Dresselhaus, G.; Saito, R. Carbon 1995, 33, $883-891$.

(3) Okamoto, A.; Gunjishima, I.; Inoue, T.; Akoshima, M.; Miyagawa, H.; Nakano, T.; Baba, T.; Tanemura, M.; Oomi, G. Carbon 2011, 49, 294-298.

(4) Baughman, R. H.; Zakhidov, A. A.; de Heer, W. A. Science 2002, 297, 787-792.

(5) Gong, K.; Du, F.; Xia, Z.; Durstock, M.; Dai, L. Science 2009, 323, $760-764$.

(6) Guo, D. J.; Li, H. L. Carbon 2005, 43, 1259-1264.

(7) Wang, Y. H.; Li, Y. N.; Zang, J. B.; Huang, H. Nanotechnology 2006, 17, 3817.

(8) Morisada, Y.; Miyamoto, Y. Mater. Sci. Eng., A 2004, 381, 57-61.

(9) Fu, L.; Liu, Z.; Liu, Y.; Han, B.; Wang, J.; Hu, P.; Cao, L.; Zhu, D. Adv. Mater. 2004, 16, 350-352.

(10) Korneva, G.; Ye, H.; Gogotsi, Y.; Halverson, D.; Friedman, G.; Bradley, J.-C.; Kornev, K. G. Nano Lett. 2005, 5, 879-884.

(11) Jitianu, A.; Cacciaguerra, T.; Benoit, R.; Delpeux, S.; Béguin, F.; Bonnamy, S. Carbon 2004, 42, 1147-1151.

(12) Jiang, L.; Gao, L. Mater. Chem. Phys. 2005, 91, 313-316.

(13) Liang, Y. X.; Chen, Y. J.; Wang, T. H. Appl. Phys. Lett. 2004, 85, 666-668.

(14) Farmer, D. B.; Gordon, R. G. Nano Lett. 2006, 6, 699-703.

(15) Piticescu, R. M.; Piticescu, R. R.; Taloi, D.; Badilita, V. Nanotechnology 2003, 14, 312.

(16) Lu, J.; Zang, J. B.; Shan, S. X.; Huang, H.; Wang, Y. H. Nano Lett. 2008, 8, 4070-4074.

(17) Luo, T. Y.; Liang, T. X.; Li, C. S. Mater. Sci. Eng., A 2004, 366, 206-209.

(18) Liang, R.; Deng, M.; Cui, S.; Chen, H.; Qiu, J. Mater. Res. Bull. 2010, 45, 1855-1860.

(19) Song, H.; Qiu, X.; Li, F. Appl. Catal., A 2009, 364, 1-7.

(20) Guo, D.; Qiu, X.; Zhu, W.; Chen, L. Appl. Catal., B 2009, 89, $597-601$.

(21) Javey, A.; Kim, H.; Brink, M.; Wang, Q.; Ural, A.; Guo, J.; Mcintyre, P.; Mceuen, P.; Lundstrom, M.; Dai, H. Nature 2002, 1, 241-246.

(22) Pal, K.; Kang, D. J.; Zhang, Z. X.; Kim, J. K. Langmuir 2010, 26, $3609-3614$.

(23) Sun, Z.; Zhang, X.; Na, N.; Liu, Z.; Han, B.; An, G. J. Phys. Chem. B 2006, 110, 13410-13414.

(24) Shan, Y.; Gao, L. Nanotechnology 2005, 16, 625-630.

(25) Lupo, F.; Kamalakaran, R.; Scheu, C.; Grobert, N.; Rühle, M. Carbon 2004, 42, 1995-1999.

(26) Banerjee, S.; Hemraj-Benny, T.; Wong, S. S. Adv. Mater. 2005, $17,17-29$.

(27) Lu, Y.; Bangsaruntip, S.; Wang, X.; Zhang, L.; Nishi, Y.; Dai, H. J. Am. Chem. Soc. 2006, 128, 3518-3519.

(28) Meng, X.; Geng, D.; Liu, J.; Li, R.; Sun., X. Nanotechnology 2011, 22, 165602.

(29) Meng, X.; Zhong, Y.; Sun, Y.; Banis, M. N.; Li, R.; Sun, X. Carbon 2011, 49, 1133-1144.

(30) Meng, X.; Zhang, Y.; Sun, S.; Li, R.; Sun, X. J. Mater. Chem. 2011, 21, 12321-12330.

(31) Meng, X.; Ionescu, M.; Banis, M.; Zhong, Y.; Liu, H.; Zhang, Y.; Sun, S.; Li, R; Sun, X. J. Nanopart. Res. 2011, 13, 1207-1218.

(32) Meng, X.; Geng, D.; Liu, J.; Banis, M.; Zhang, Y.; Li, R.; Sun, X. J. Phys. Chem. C 2010, 114, 18330-18337.

(33) Chen, Y.; Wang, J.; Meng, X.; Zhong, Y.; Li, R.; Sun, X.; Ye, S.; Knights, S. Int. J. Hydrogen Energy 2011, 36, 11085-11092.

(34) Li, X.; Meng, X.; Liu, J.; Geng, D.; Zhang, Y.; Banis, M.; Li, Y.; Li, R.; Sun, X.; Cai, M.; Verbrugge, M. Adv. Funct. Mater. 2012, DOI: $10.1002 / \mathrm{adfm} .201101068$.

(35) George, S. M. Chem. Rev. 2010, 110, 111-131.

(36) Puurunen, R. L. J. Appl. Phys. 2005, 97, 121301-121352.

(37) Nam, W.-H.; Rhee, S.-W. Chem. Vap. Deposition 2004, 10, 201205.

(38) Hausmann, D. M.; Kim, E.; Becker, J.; Gordon, R. G. Chem. Mater. 2002, 14, 4350-4358.
(39) Hausmann, D. M.; Gordon, R. G. J. Cryst. Growth 2003, 249, 251-261.

(40) Becker, J. S.; Kim, E.; Gordon, R. G. Chem. Mater. 2004, 16, 3497-3501.

(41) Liu, H.; Arato, D.; Li, R; Zhang, Y.; Merel, P.; Sun, X. Surf. Coat. Technol. 2008, 202, 4114-4120.

(42) Zhong, Y.; Jaidann, M.; Zhang, Y.; Zhang, G.; Liu, H.; Ionescu, M. I.; Li, R.; Sun, X.; Abou-Rachid, H.; Lussier, L.-S. J. Phys. Chem. Solids 2010, 71, 134-139.

(43) Liu, H.; Zhang, Y.; Li, R.; Sun, X.; Désilets, S.; Abou-Rachid, H.; Jaidann, M.; Lussier, L.-S. Carbon 2010, 48, 1498-1507.

(44) Hirata, T.; Asari, E.; Kitajima, M. J. Solid State Chem. 1994, 110, 201-207.

(45) Keramidas, V. G.; White, W. B. J. Am. Ceram. Soc. 1974, 57, $22-$ 24.

(46) Ferrari, S.; Dekadjevi, D. T.; Spiga, S.; Tallarida, G.; Wiemer, C.; Fanciulli, M. J. Non-Cryst. Solids 2002, 303, 29-34.

(47) Chen, L.; Mashimo, T.; Omurzak, E.; Okudera, H.; Iwamoto, C.; Yoshiasa, A. J. Phys. Chem. C 2011, 115, 9370-9375.

(48) Pitcher, M. W.; Ushakov, S. V.; Navrotsky, A.; Woodfield, B. F.; Li, G.; Boerio-Goates, J.; Tissue, B. M. J. Am. Ceram. Soc. 2005, 88, 160-167.

(49) Garvie, R. C. J. Phys. Chem. 1965, 69, 1238-1243.

(50) Puurunen, R. L.; Vandervorst, W.; Besling, W. F. A.; Richard, O.; Bender, H.; Conard, T.; Zhao, C.; Delabie, A.; Caymax, M.; Gendt, S. D.; et al. J. Appl. Phys. 2004, 86, 4878-4889.

(51) Copel, M.; Gribelyuk, M.; Gusev, E. Appl. Phys. Lett. 2000, 76, 436-438.

(52) Besling, W. F. A.; Young, E.; Conard, T.; Zhao, C.; Carter., R.; Vandervorst., W.; Caymax, M.; De Gendt, S.; Heyns, M.; Maes, J.; et al. J. Non-Cryst. Solid 2002, 303, 123-133.

(53) Min, Y. S.; Lee, II H.; Lee, Y. H.; Hwang, C. S. CrystEngComm 2011, 13, 3451-3454.

(54) Sun, C.-L.; Chen, L.-C.; Su, M.-C.; Hong, L.-S.; Chyan, O.; Hsu, C.-Y.; Chen, K.-H.; Chang, T.-F.; Chang, L. Chem. Mater. 2005, 17, 3749-3753.

(55) Sun, S.; Zhang, G.; Zhong, Y.; Liu, H.; Li, R.; Zhou, X.; Sun, X. Chem. Commun. 2009, 45, 7048-7050.

(56) Choi, H. C.; Bae, S. Y.; Jang, W.-S.; Park, J.; Song, H. J.; Shin, H.-J.; Jung, H.; Ahn, J.-P. J. Phys. Chem. B 2005, 109, 1683-1688.

(57) Rodríguez-Reyes, J. C. F.; Teplyakov, A. V. J. Appl. Phys. 2008, $104,084907$.

(58) Matero, R.; Rahtu, A.; Ritala, M.; Leskelä, M.; Sajavaara, T. Thin Solid Films 2000, 368, 1-7.

(59) Cassir, M.; Goubin, F.; Bernay, C.; Vernoux, P.; Lincot, D. Appl. Surf. Sci. 2002, 193, 120-128.

(60) Aarik, J.; Aidla, A.; Sammelselg, V.; Siimon, H.; Uustare, T. J. Cryst. Growth 1996, 169, 496-502.

(61) Ritala, M.; Leskelä, M. Appl. Surf. Sci. 1994, 75, 333-340.

(62) Kukli, K.; Ritala, M.; Asrik, J.; Uustare, T. J. Appl. Phys. 2002, 92, $1833-1840$.

(63) Scarel, G.; Ferrari, S.; Spiga, S.; Wiemer, C.; Tallarida, G.; Fanciulli, M. J. Vac. Sci. Technol., A 2003, 21, 1359-1365.

(64) Aarik, J.; Aidla, A.; Uustare, T.; Sammelselg, V. J. Cryst. Growth 1995, 148, 268-275.

(65) Ritala, M.; Leskelä, M.; Niinistö, L.; Prohaska, T.; Friedbacher, G.; Grasserbauer, M. Thin Solid Films 1994, 250, 72-80.

(66) Goodman, C. H. L.; Pessa, M. V. J. Appl. Phys. 1986, 60, R65R81.

(67) Aarik, J.; Aidla, A.; Mändar, H.; Uustare, T.; Sammelselg, V. Thin Solid Films 2002, 408, 97-103. 